\title{
The Impact of Leadership Styles on the Entrepreneurial Orientation of Small and Medium Enterprises
} in South Africa

\author{
Obey Dzomonda, Olawale Fatoki, Olabanji Oni \\ University of Limpopo, Turflop Campus, South Africa \\ obeydzoms@gmail.com, olawale.fatoki@ul.ac.za, olabanji.oni@ul.ac.za
}

\begin{abstract}
The critical role Small and Medium Enterprises play in the economic prosperity of nations cannot be understated. SMEs actively contribute towards economic growth and development through their active role as innovators and agents for change. The authors of this paper believe that leadership styles exercised by SME owners have a bearing on the innovative ability of SMEs. Hence, this paper aimed at investigating the impact of leadership styles on the entrepreneurial orientation of SMEs in Polokwane Municipality. A quantitative research method was used and 103 SMEs participated in the survey. The random sampling technique was used. Self-administered questionnaires were utilised to collect data in a survey. Data analysis included descriptive statistics, Pearson's correlation and regression analysis. Reliability of the data collection instruments was measured using the Cronbach's alpha. The results indicated that the SMEs display average levels of entrepreneurial orientation. In addition, the results showed that SMEs display average levels of leadership styles inclined towards transformational leadership style. Furthermore, the results showed a significant positive relationship between the independent variables: leadership styles with the dependent variable (EO) of SMEs. SMEs were recommended to provide flexible leadership styles that will make EO to flourish in their businesses. Furthermore, the policy makers and relevant authorities were recommended to devise and implement a consortium of strategies and policies that can increase the level of entrepreneurial orientation among SMEs in South Africa.
\end{abstract}

Keywords: Entrepreneurial orientation, leadership style, SMEs, South Africa

\section{Introduction}

There is growing importance for SMEs in various countries worldwide but most particularly in developing countries (Lekhanya, 2013).Unemployment in South Africa is estimated to be 27.1\% (Statistics South Africa, 2016). The SME sector has been identified as a possible antidote to pressing challenges facing South Africa (Fatoki, 2012). As remarked by Abor and Quartey (2010), SMEs form a large percentage of formal business entities in South Africa, contributing above 50\% towards total economic activity in the country. This contribution is sufficient to alert policy makers of how significant this sector is to the economy of South Africa. Worryingly, as noted by Fatoki and Garwe (2010), most small businesses in South Africa are haunted by premature death. In most instances, this is characterised by most small businesses failing in the introductory phase and others within the range of one to five years. According to Adeniran and Johnston (2011), the statistics of small businesses dying every year is recurrent and is recorded to be at least $70 \%$ and $80 \%$ at most, which is extremely high. Given such alarming statistics, debate has risen among scholars and policy makers whether this sector carries the so much anticipated solutions to a plethora of challenges facing South Africa. Bowen, Morara and Mureithi (2009) indicate the need to investigate factors, which can enhance SMEs' survival and growth. Fatoki (2014) finds that the factors, which inhibit SME growth and survival in South Africa, include internal as well as external elements of the business environment. Furthermore, the random failure of SMEs is also due to the weaknesses in their strategic framework and their inability to adopt EO (Awang, Ahmad, Asghar \& Subari, 2010).

Studies such as Zulkifli and Rosli (2013) and Murimbika (2012) found that EO is important for SMEs survival and growth. EO is exhibited in businesses which are proactive, risky tolerant and embark on innovation to stay ahead of possible competitors (Palalic \& Busatlic, 2015). Shahraki and Bahraini (2013) note that E0 refers to owner or manager's strategy regarding innovation, leadership and risk taking. Van Geenhuizen, Middel and Lassen (2008) remark that EO has emerged as a sustainable solution to a plethora of challenges faced by various businesses. Thus, this study is of the argument that a well-implemented EO strategy can go a long way towards enhancing the survival and growth of small businesses in this country. A number of elements affect the entrepreneurial orientation of SMEs. Brettel, Chomik \& Flatten (2014) and Muneer et al. (2014) identify organisational structure, leadership styles and organisational culture as some of the key 
drivers of entrepreneurial orientation. Arham, Boucher and Muenjohn (2013) observe that SMEs need effective leadership styles and EO to be successful in their business endeavours. Studies on EO in South Africa such as Mohutsiwa (2012), Bahula (2013), Matchaba-Hove, and Farrington (2015) have focused on its impact on performance. This study is driven by the goal to find out how the leadership styles employed by SMEs affect their entrepreneurial orientation.

Objectives: The objectives of the study were: (1) to identify the entrepreneurial orientation (EO) of SMEs (2) to determine the leadership styles of SMEs and (3) to investigate the relationship between leadership styles and the entrepreneurial orientation of SMEs.

\section{Hypotheses}

$\mathbf{H}_{\mathbf{0}}$ : There is no link between leadership style and the entrepreneurial orientation of SMEs.

$\mathbf{H}_{\mathbf{1}}$ : There is a significant link between leadership style and the entrepreneurial orientation of SMEs.

\section{Literature Review}

This study derives its theoretical support from two theories namely: entrepreneurial orientation theory and the leadership style theory respectively.

Theory of Entrepreneurial Orientation: The EO concept dates back to the 1970s (Covin \& Wales, 2011). As one of the early contributors to the field, Mintzberg (1973), indicate EO as the key element in any entrepreneurial firm. According to Khandwalla (1976/1977), EO orientated firms ought to be dynamic, creative and vibrant to stay ahead of their competitors. SMEs driven by E0 tend to integrate elements like risky taking, proactiveness and innovativeness to come up with a new product that drives competitors off the market (Miller, 1983). As Covin and Slevin (1988) indicate, leaders who have an E0 mindset should lead entrepreneurially driven organisations. Covin and Slevin (1989) note that businesses in more competitive and unstable environments should consider embracing the EO concept compared to their counterparts who operate in more stable business environments. According to Miller (1983), the EO scale consists of innovativeness, risk taking, and proactiveness. A significant number of studies in the existing literature have used the above three measure of EO, reporting high levels of reliability and validity. Lumpkin and Dess (1996) added aggressiveness and autonomy to the existing EO measures. They argued that this could be able to give an in-depth and dependable measure. This contribution adopts a unidimensional approach to EO by focusing on the three aspects of entrepreneurial orientation conceptualised by Miller (1983).

The EO theory provides an important framework for researching entrepreneurial activity, which is a key ingredient towards high performance of SMEs. SMEs in South Africa should consider incorporating EO in their organisations if they are to survive and grow into future large firms that provide a dependable job creation capacity (Fatoki, 2012). EO is associated with high firm growth (Mwangi \& Ngugi, (2014). Muchiri and McMurray (2015) note that firms, which invest on EO, outcompete their rivals in most cases. Many factors can affect the entrepreneurial orientation of SMEs. According to Musa, Ghani and Ahmad (2011), these factors can be internal or external. Internal factors include organisational structure, leadership style, firm size and management techniques among others while external factors include state of the economy, growth and trends in the industry, government rules and regulations (Musa et al., 2011). This study chooses to elaborate on internal factors that affect EO particularly leadership styles. According to Miller (2011), current literature emphasises a need to explore more on internal factors affecting EO.

Leadership Style Theory: Manaf and Latif (2014) defined leadership style as a pattern of behaviour or attitude displayed by a leader in his/her area of influence. To help explain leadership styles various theories have been postulated. These include Burns (1978) and Bass (1985). Bass (1985) built on Burns's (1978) concept of leadership style comprising of transformational and transactional leadership style by adding the laissez-faire leadership style. Avolio and Bass (1991) developed a full-fletched leadership theory to improve on the existing measures. This study focused on transformational and transactional leadership style. The use of laisez faire leadership style has become uncommon in the existing literature hence a decision to drop it in this study. 
Transformational Leadership Style: Tarsik, Kassim and Nasharudin (2014) define transformational leadership style as a style demonstrated by leaders who are driven by the desire to unleash the best out of their followers, which enhance productivity and morale in the entire organisation. On that note, the author of this paper believes that transformational leadership style is a key ingredient for firms aiming to reduce high rates of absenteeism, resistance to change and undesirable levels of turnover. Kwasi (2015) further describe transformational leadership as a leadership style where the leader takes an inclusive approach towards meeting the desired targets. Transformational leaders are optimistic, exhibit enthusiasm and they emphasize commitment to a shared goal (Lai, 2011). According to Bass (1985) transformational leadership, style consists of five factors: inspirational motivation- charisma idealised influence, intellectual stimulation and individualised consideration.

Transactional Leadership Style: According to Tarsik et al. (2014), transactional leadership style is exhibited in situations where gains are realised after certain set standards are met. For example, management can set individual goals, which each person should accomplish to get a bonus or a salary increase. However, this is made transactional in that employees will also demand certain resources and support from management to meet the set targets at specified deadlines. Kwasi (2015) remarks that transactional leaders are more task-or goal-oriented than people-oriented. On that note, transactional leaders define objectives and set expectations from each employee prior to the execution of the task (Martin, 2015). For the purpose of this study, transactional leadership style is explained in terms of two factors: contingent reward ad management-byexception.

Leadership styles and entrepreneurial orientation: Businesses in this $21^{\text {st }}$ century are exposed to a plethora of challenges such as stiff competition, short product life cycles among others all emanating from globalisation. Organisations are therefore required to adapt to the dynamic business environment lest they risk going out of business. It calls for transformational leaders who can initiate change to replace old systems with new ones to keep businesses relevant in the markets they serve. A plethora of studies on EO-leadership relationship has focused mainly on large organisations rather than on SMEs (Muchiri \& McMurray, 2015). On that note, it is crucial to understand how it is applied in SMEs bearing in mind that both resources and management to support EO differ greatly between large organisations and SMEs (Muchiri \& McMurray, 2015). The context of this study is to link EO of SMEs with each leadership style. According to Panagopoulos and Avlonitis (2010), leadership style is a crucial requirement if a firm desire to adopt an EO strategy successfully.Transformational leadership style is perfectly suited for firms considering adopting EO(Shahraki \& Bahraini, 2013). On that note, transformational leaders actively promote creativity and information transfer through their charismatic behaviour (Shahraki \& Bahraini, 2013). Studies such as (Nahavandi, 2006) indicate that a transactional leader creates an entrepreneurial orientation atmosphere in the organisation through the concept of exchange. The leader promises the followers some benefits if they meet or surpass the set targets. Various studies like, Oncer, (2013); Shahraki and Bahraini, (2013); Arham et al. (2013) report a significant link between leadership style and entrepreneurial orientation. This paper argues that the development of good leadership style can be a remarkable step towards improving the EO of SMEs.As such; the authors of this paper believe that a significant association exists between leadership style and EO.

\section{Methodology}

This paper utilised a quantitative research methodology.The respondents were randomly selected to give each SME a chance to be selected. The study area was Polokwane in the Limpopo province of South Africa.Self-administered questionnaires were utilised in a survey to collect data from the respondents following similar studies (Arham et al., 2013; Arham, 2014). Closed ended questions were used where respondents were limited to respond to a set of answers provided in the questionnaire. The questionnaire for the study consisted of three sections; (1) Biographical questions (2) Entrepreneurial orientation and (3) Leadership style. The questionnaire was adapted from existing literature. This questionnaire was used following similar studies on EO (Fatoki, 2012; Soininen, 2013; Mahmood \& Hanafi, 2013) where the tool showed high levels of reliability and validity. The Multifactor Leadership Questionnaire (MLQ) to measure leadership styles was adopted from Avolio and Bass (2004). A sample of 103 SME owner/managers participated in the survey. Likert scale questions ranging from: strongly disagree to strongly agree were 
utilised in the study to obtain data. Data analysis included descriptive statistics, regression analysis and Pearson correlation coefficient. Reliability was measured using the Cronbach's alpha.

\section{Research Results and Discussion}

Normality can be tested using the Kolmogorov-Smirnov test. This tool was used to test normality since the sample size of 250 SMEs was above the stipulated 100 and above sample size. The Kolmogorov-Smirnov test showed significance measures greater than 0.05 . Therefore, it can be deduced that the requirement for normality is satisfied.

Response rate: Table 1 above reflects the response rate of the study. Two hundred and fifty questionnaires were distributed to SMEs in Polokwane Municipality and one hundred and three questionnaires were returned. The response rate was forty-one percent.

Table 1: The response rate

\begin{tabular}{llll}
\hline Respondents & No. of questionnaires sent & No. Returned & Response rate \\
\hline SME owners/managers & 250 & 103 & $41 \%$ \\
\hline
\end{tabular}

Biographical information: Majority of the participants were males (63\%) compared to only (37\%) females, falling in the 31-40 age group. This is consistent with studies such as Garwe and Fatoki (2012) as well as Brijlal, Naicker and Peters (2013) which points out that male still own more SMEs than females in South Africa. According to Wealthwise (2014), this huge gap is attributed to the fact that women find it difficult to create a family-work balance. From the findings, it was discovered that the majority (38\%) of the respondents of the study have matric qualification. The findings are consistent with the results of Van der Merwe and de Swardt (2008) and Agbenyegah (2013) that individuals with matric own a sizeable percentage of small businesses or equivalent qualifications. A significant number of SMEs (34\%) are sole proprietors with majority of them in the retail sector. It was discovered that majority of SMEs employ 1-5 people which indicate that SMEs' contribution to employment creation is relatively weak. Fin Mark Trust (2015) attributes this to the reason that most of them do not grow. Worryingly the results showed that most of the SMEs (41\%) have been in operation for between 1 and five years. The findings tally with similar studies (Fatoki \& Garwe, 2010) which report that SMEs in South Africa fail in the early stages of the business growth phase.

Factor analysis: Factor analysis aims at reducing the many observable variables into fewer meaningful categories (Yong \& Pearce, 2013). Factor analysis was run to check if the variables of the entrepreneurial orientation and leadership styles tally confirm the underlying variables as indicated in the existing literature. Furthermore, this tool was used to verify the discriminant construct validity of measures. Using this statistical analysis tool, items loading above 0.5 and those loading only to one factor loading were considered for further statistical analysis.

Table 2: Factor analysis results of EO variables

\begin{tabular}{|c|c|c|c|}
\hline EO Measures & $\begin{array}{l}\text { Factor 1 } \\
\text { Innovativeness }\end{array}$ & $\begin{array}{l}\text { Factor } 2 \\
\text { Proactiveness }\end{array}$ & $\begin{array}{l}\text { Factor } 3 \\
\text { Risk taking }\end{array}$ \\
\hline 1. My business has introduced a number of new & & & \\
\hline lines of products and services recently. & 0.741 & & \\
\hline $\begin{array}{l}\text { 2. We have experienced dynamic changes in our } \\
\text { products and services in recent times. }\end{array}$ & 0.663 & & \\
\hline $\begin{array}{l}\text { 3. My business is generally inclined towards new } \\
\text { product and development. }\end{array}$ & 0.434 & & \\
\hline $\begin{array}{l}\text { 5. My business aims to always be the first to } \\
\text { introduce new products or services in the market. } \\
\text { 6. My business always takes a proactive stance }\end{array}$ & & 0.717 & \\
\hline when dealing competitors. & & 0.637 & \\
\hline $\begin{array}{l}\text { 7. Due to the dynamic nature of the business } \\
\text { environment, our business takes a bold stance in }\end{array}$ & & & 0.724 \\
\hline
\end{tabular}


order to meet our goals.

8. My business tends to be aggressive in order take

advantage of opportunities.

0.691

9. My business has a huge appetite for high

risk/high return projects.

Eigen value

Percentage of variance explained (74.52\%).

28.36

0.743

0.593

1.49

Cronbach's alpha

2.35

18.73

Source: Principal components factor analysis with varimax rotation. Kaiser-Meyer-Olkin (KMO) test of sampling adequacy $=0.74 ;$ Barlett Test of Sphericity $(B T S)=459.879, p=0.000$

Factor analysis for entrepreneurial orientation measures: Table 2 shows factor analysis results. As shown above, three factors with Eigen values greater than one were identified. These are innovation consisting of three variables, proactiveness consisting of two variables and factor three is identified as risktaking and is made up of three variables. The Cronbach's alphas are greater than 0.700 . This is consistent with other studies (Fatoki, 2012; Filler, 2013; Arham, 2014). The factor analysis was able to retain all the variables from the original tool adapted from Miller (1983). This suggests that all the variables above sufficiently measure the underlying EO factors.

Table 3: Factor analysis for transformational leadership style

\begin{tabular}{|c|c|c|c|}
\hline Transformational Leadership Style Measures & $\begin{array}{l}\text { Factor } \\
\text { 1idealised } \\
\text { influence }\end{array}$ & $\begin{array}{l}\text { Factor } 2 \\
\text { Intellectual } \\
\text { stimulation } \\
\end{array}$ & $\begin{array}{l}\text { Factor } \\
\text { Inspir } \\
\text { motive }\end{array}$ \\
\hline $\begin{array}{l}\text { 1. I strive to make my employees valuable when they } \\
\text { are with me. }\end{array}$ & 0.86 & & \\
\hline 8. My employees totally trust me. & 0.76 & & \\
\hline 15. My employees enjoy my company. & 0.68 & & \\
\hline $\begin{array}{l}\text { 3. I challenge my employees to develop new problem } \\
\text { solving techniques. }\end{array}$ & & 0.83 & \\
\hline $\begin{array}{l}\text { 10. I teach my employees to be creative to improve } \\
\text { the way they view things around them. }\end{array}$ & & 0.67 & \\
\hline $\begin{array}{l}\text { 17. I get others to rethink ideas that they had never } \\
\text { questioned before. }\end{array}$ & & 0.60 & \\
\hline $\begin{array}{l}\text { 2. I express with a few simple words what we could } \\
\text { and should do. }\end{array}$ & & & 0.78 \\
\hline 9. I provide appealing images about what we can do. & & & 0.66 \\
\hline 16. I help others find meaning in their work. & & & 0.58 \\
\hline Eigen value & 3.43 & 2.12 & 1.69 \\
\hline Percentage of variance explained (64.79\%) & 24.32 & 21.42 & 19.05 \\
\hline Cronbach's alpha & 0.77 & 0.78 & 0.74 \\
\hline
\end{tabular}

Source: Principal components factor analysis with varimax rotation. Kaiser-Meyer-Olkin (KMO) test of sampling adequacy $=0.79$; Barlett Test of Sphericity $(B T S)=489.001, p=0.001$.

Factor analysis for transformational leadership style: Table 3 present factor analysis results for transformational leadership style. Three factors were identified: Factor 1 Idealised influence, Factor 2 Intellectual stimulation and Factor 3 Inspirational motivation. Items from individualised consideration were dropped as their factor loadings were less than 0.5. The results are consistent with the findings of (Arham, 2014).

Factor analysis for transactional leadership style: As shown above two factors with Eigen values greater than one were identified. These are Factor 1 Contingent Reward and Factor 2 Management by Exception with three items each. The results indicate that SME owners/managers clearly specify standards expected of employees. 


\begin{tabular}{l} 
Journal of Economics and Behavioral Studies (ISSN: 2220-6140) \\
Vol. 9, No. 2, pp. 104-113, April 2017 \\
\hline \hline
\end{tabular}

Table 4: Factor analysis for transactional leadership style

Transactional Leadership Style Measures

$\begin{array}{cc}\text { Factor } 1 & \text { Factor } 2 \\ \text { Contingent } \\ \text { Reward }\end{array} \quad \begin{gathered}\text { Management by } \\ \text { Exception }\end{gathered}$

5. I clearly tell my employees what is expected of them to get a reward.

12. In my organisation we reward employees when they meet the set $\quad 0.76$

goals.

19. I clearly state the rewards associated with a certain output 0.57 beforehand.

6. It pleases me when my employees meet the set goals and targets. 0.78

13. I normally don't change anything if workplace activities are 0.76

smoothly flowing.

20. I clarify the job specifications so that employees know the

standards they have to meet.

Eigen value

Percentage of variance explained (53.82\%)

2.61

1.94

Cronbach's alpha

28.47

25.35

Source: Principal components factor analysis with varimax rotation. Kaiser-Meyer-Olkin (KMO) test of sampling adequacy $=0.79$; Barlett Test of Sphericity $(B T S)=479.001, p=0.001$

\section{Hypothesis Testing}

Table 5: Correlation results

\begin{tabular}{lllll}
\hline Correlations & E0 & $\begin{array}{c}\text { Transformational } \\
\text { leadership style }\end{array}$ & $\begin{array}{c}\text { Transactional } \\
\text { leadership style }\end{array}$ \\
\hline EO & Pearson Correlation & 1 & $.870^{* *}$ & $.626^{*}$ \\
& Sig. (2-tailed) & & .000 & .022 \\
& $\mathrm{~N}$ & 103 & 103 & 103 \\
Transformational & Pearson Correlation & $.870^{* *}$ & 1 & $.606^{* *}$ \\
leadership style & Sig. (2-tailed) & .000 & & .000 \\
& $\mathrm{~N}$ & 103 & 103 & 103 \\
Transactional & Pearson Correlation & $.626^{*}$ & $.606^{* *}$ & 1 \\
leadership style & Sig. (2-tailed) & .022 & .000 & 103 \\
& $\mathrm{~N}$ & 103 & 103 & \\
\hline
\end{tabular}

Link between leadership styles and entrepreneurial orientation: Table 5 above shows the correlation results. The correlation between EO and transformational leadership is $(r=0.870, p=0.000)$ while the correlation between EO and transactional leadership style is $(r=0.626, p=0.022)$. The findings show that the two leadership styles are positively correlated to EO however mostly with transformational leadership style. The results support the hypothesis that there is a significant link between leadership styles and EO of SMEs. The findings tally with other studies, which investigated similar concepts (Oncer, 2013; Shahraki \& Bahraini, 2013; Arham et al., 2013).

Link between leadership styles and entrepreneurial orientation: Table 6 above shows regression analysis results. The regression analysis results between transformational, transactional leadership style and EO are $(B=0.195$, sig $=0.000$ and $B=0.105$, sig $=0.000)$ respectively. The results support the alternative hypothesis $\left(\mathbf{H}_{\mathbf{1}}\right)$ that there is a significant link between leadership style and the entrepreneurial orientation of SMEs. Based on the confidence interval of $95 \%$ and Sig. $>0.05$ this led to the decision to reject the null hypothesis $\left(\mathbf{H}_{\mathbf{0}}\right)$ and accept the alternative hypothesis $\left(\mathbf{H}_{\mathbf{1}}\right)$. The results are consistent with studies (Nahavandi, 2006; Shahraki \& Bahraini, 2013; Oncer, 2013). 
Table 6: Regression analysis results

\begin{tabular}{llll}
\hline Independent variables & Beta & T & Sig \\
\hline Transformational leadership style & 0.195 & 44.910 & .000 \\
Transactional leadership style & 0.105 & 22.799 & .000 \\
\hline
\end{tabular}

Source: Data Analysis. Dependent variable: Entrepreneurial orientation. Sig. $>0.05$

\section{Conclusion}

The argument of this study was that entrepreneurial orientation is a possible antidote to a plethora of challenges causing SMEs in South Africa to fail. Therefore, it was of significance to understand the factors that improvement repreneurial orientation. It was deduced that leadership style significantly predicts EO of SMEs. The results indicated that the owners/managers display average levels of entrepreneurial orientation. In addition, the results showed that SMEs display average levels of leadership styles inclined towards transformational leadership style. From hypothesis testing, $\left(\mathbf{H}_{\mathbf{0}}\right)$ was rejected. The final decision was to accept the alternative hypothesis. It was concluded that leadership style is significantly linked to EO. This calls for a strong need to improve on this factor since it's a crucial determinant of EO in firms. The findings of this study serve an important role towards contributing empirically and theoretically to the existing EO literature as well as an aid for policy making as will be discussed below. Recommendations to policy makers and SMEs owners/managers on the different measures they can embark on to improve EO were suggested in the following section.

Recommendations: The statistics of SMEs struggling to reach their projected growth targets is on the rise in South Africa. This raises questions on whether SMEs are a sustainable solution to a plethora of problems haunting South Africa. The authors believe that an entrepreneurial orientation strategy can be a panacea to the random SMEs failure in South Africa. Recommendations are made towards two crucial bodies; SMEs and the government (policymaking body).

SME owner/managers: It has been noted from empirical findings that leadership style is a good predictor of EO. Hence SMEs are recommended to provide flexible leadership styles that will make EO to flourish in their businesses. Furthermore, SMEs are recommended to maintain a mix of the two leadership styles (transformational and transactional) since they complement each other. In addition, the reward systems both monetary and non-monetary for SMEs should be structured in a way to encourage EO.

Government (policy making body): The results obtained from this study should give policy makers and relevant authorities a firm ground to devise and implement a consortium of strategies and policies that can increase the level of entrepreneurial orientation among SMEs in South Africa. Some of the policies may include the following:

- The government can also help SME owners acquire and improve their leadership styles and entrepreneurial orientation by creating entrepreneurship training centres in all the provinces in South Africa. This should be made easily accessible to all deserving SME owners from different sectors.

- Role models play a critical role towards motivating entrepreneurs. On that account the government should through its different bodies, conduct workshops where prominent entrepreneurs are given a platform to share their success stories.

- Policy makers should also embark on a more comprehensive support including the collaboration of all sectors in the society.

- Furthermore, the government should put in place business incubation and mentorship services to assist SMEs from start-up to until the growth stage. This should include practices whereby the government makes it a requirement for large organisations to be business incubators for one or two SMEs. However, the government will need to incentivise these large organisations to make the initiative sustainable. 


\section{References}

Abor J. \& Quartey, P. (2010). Issues in SME development in Ghana and South Africa. International Research Journal of Finance and Economics, 1(39), 218-228.

Adeniran, T. \& Johnston, A. (2011). Investigating the level of internet capabilities of South African small and medium enterprises in changing environments. Online at http://www.zaw3.co.za/index.php/ZAwww/2011/paper/view/450. Accessed on 26 June 2015.

Agbenyegah, A.T. (2013). Challenges facing rural entrepreneurship in selected areas in South Africa. Thesis. North-West University.

Arham, A. F. (2014). The relationship between leadership behaviour, entrepreneurial orientation and organisational performance in Malaysian small and medium enterprises. Thesis, Royal Melbourne Institute of Technology University.

Arham, A. F., Boucher, C. \& Muenjohn, N. (2013). Leadership and entrepreneurial success: a study of SMEs in Malaysia. World Journal of Social Sciences, 3(5), 117-130.

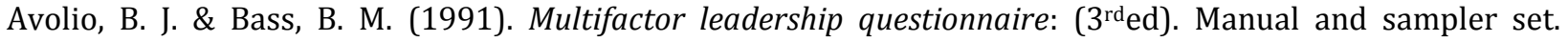
Redwood City, CA: Mind Garden.

Avolio, B. J. \& Bass, B. M. (2004). Multifactor leadership questionnaire: (3 ${ }^{\text {rd }}$ ed). Manual and sampler set. Redwood City, CA: Mind Garden

Awang, A., Ahmad, Z. A., Asghar, A. R. S. \& Subari, K. A. (2010). Entrepreneurial orientation among Bumiputera small and medium agro-based enterprises (BSMAEs) in West Malaysia: Policy implication in Malaysia. International Journal of Business and Management, 5(5), 13-143.

Bahula, M. A. (2013). The impact of entrepreneurial orientation on performance in the metals and engineering industry. Dissertation (MBA). University of Pretoria, South Africa.

Bass, B. M. (1985). Leadership and performance beyond expectation. New York: The Free Press.

Bowen, M., Morara, M. \& Mureithi, S. (2009). Management of business challenges among small and micro enterprises in Nairobi-Kenya. KCA. Journal of Business Management, 2(1), 16-31.

Brettel, M., Chomik, C. \& Flatten, T. C. (2014). How organisational culture influences innovativeness, proactiveness and risk-taking: fostering entrepreneurial orientation in SMEs. Online at http://onlinelibrary.wiley.com/doi/10.1111/jsbm.12108/pdf/ Accessed on 26 June 2015.

Brijlal, P., Naicker, V. \& Peters, R. (2013). Education and SMME business growth: a gender perspective from South Africa. International Business \& Economics Research Journal, 12(8), 855-866.

Burns, J. M. (1978). Leadership. New York. Harper \& Row.

Covin, J. G. \& Slevin, D. P. (1988). The influence of organisation structure on the utility of entrepreneurial top management style. Journal of Management Studies, 25(3), 217-234.

Covin, J. G. \& Slevin, D. P. (1989). Strategic management of small firms in hostile and benign environments. Strategic Management Journal, 10, 75-87.

Covin, J. G. \& Wales, W. J. (2011). The measurement of entrepreneurial orientation. Entrepreneurship Theory and Practice, 1(1), 1-26.

Fatoki, O. \& Garwe, D. (2010). Obstacles to the growth of new SMEs in South Africa: A principal component analysis approach. African Journal of Business Management, 4(5), 729-738.

Fatoki, 0. (2012). The impact of entrepreneurial orientation on access to debt finance and performance of small and medium enterprises in South Africa. Journal of Social Science, 32(2), 121-131.

Fatoki, 0. (2014). The causes of the failure of new small and medium enterprises in South Africa. Mediterranean Journal of Social Sciences, 5(20), 922-927.

Filler, K. S. (2013). An Analysis of Leadership Styles and Entrepreneurial Orientation of Executives within the Licensed Assisted Living Facility Industry in Indiana. Indiana Wesleyan University.

FinMark Trust. (2015). Financial access and SME size in South Africa. Online at http://www.finmark.org.za/0e91471136eb493c9771c15a0d591dee/finaldownload/downloadida5f 7b10bf38c64bc80af7dbaacf46010/0e91471136eb493c9771c15a0d591dee/wpcontent/uploads/20 16/01/rep_financial-access-and-sme-size-insa_dec20151.pdf/Accessed on 17 March 2016.

Garwe, D. K. \& Fatoki, O. (2012). The impact of gender on SME characteristics and access to debt finance in South Africa. Development Southern Africa, 29(3), 448-461.

Khandwalla, P. N. (1976/1977). Some top management styles, their context and performance. Organisation and Admin Sciences, 7, 21-51. 
Kwasi, D. (2015). Resilient leadership: A transformational-transactional leadership mix, Journal of Global Responsibility, 6(1), 99-112.

Lai, A. (2011). Transformational-transactional leadership theory. Online at http://digitalcommons.olin.edu/ahs_capstone_2011/17/Accessed on 15 October 2015.

Lekhanya, L. M. (2013). The use of social media and social networks as the promotional tool for rural small, medium and micro enterprises in KwaZulu-Natal. International Journal of Scientific and Research Publications, 3(7), 1-7.

Lumpkin, G. T. \& Dess, G. G. (1996). Clarifying the Entrepreneurial Orientation Construct and linking it to Performance. Academy of Management Review, 21(1), 135-172.

Mahmood, R. \& Hanafi, M. (2013). Entrepreneurial Orientation and Business Performance of Women-Owned Small and Medium Enterprises in Malaysia: Competitive Advantage as a Mediator. International Journal of Business and Social Science, 4(1), 82-90.

Manaf, A. H. A. \& Latif, L. A. (2014). Transformational Leadership and Job Performance of SMEs Technical Personnel: The Adaptability Cultural Approach as Mediator. Mediterranean Journal of Social Sciences, $5(20), 648-655$.

Martin, J. (2015). Transformational and transactional leadership: an exploration of gender, experience, and institution type. Libraries and the Academy, 15(2), 331-351.

Matchaba-Hove, T., Farrington, S. \& Sharp, G. (2015). The entrepreneurial orientation- performance relationship: A South African small business perspective. South African Journal of Entrepreneurship and Small Business Management, 7, 36-68.

Miller, D. \& Friesen, P. H. (1982). Innovation in conservative and entrepreneurial firms: Two models of strategic momentum. Strategic Management Journal, 3(1), 1-25.

Miller, D. (1983). The correlates of entrepreneurship in three types of firms. Management Science, 29(7), 770791.

Miller, D. (2011). A reflection on EO research and some suggestions for the future. Entrepreneurship. Theory and Practice, 35(6), 873-894.

Mintzberg, H. (1973). Strategy-making in three modes. California Management Review, 16(2), 44-53.

Mohutsiwa, M. (2012). Strategic entrepreneurship and performance of small and medium enterprises in South Africa. Dissertation. University of the Witwatersrand, Johannesburg.

Muchiri, M. \& McMurray, A. (2015). Entrepreneurial orientation within small firms: a critical review of why leadership and contextual factors matter. Small Enterprise Research, 22(1), 17-31.

Muneer, S., Iqbal, S. M. J., Rehman, S. U. \& Long, C. S. (2014). An Incorporated Structure of Perceived Organizational Support, Knowledge-Sharing Behavior, Organizational Trust and Organizational Commitment: A Strategic Knowledge Management Approach. Pakistan Journal of Commerce and Social Sciences, 8(1), 42- 57

Murimbika, M. (2012). Influence of strategic management practices on the entrepreneurial orientation of South African firms in the financial and business services sector. Dissertation, University of the Witwatersrand, Johannesburg.

Musa, D., Ghani, A. H. \& Ahmad, S. (2011). The role of market orientation as a moderating variable in the relationship between entrepreneurial orientation and firm performance. IPBJ, 3(2), 15-31.

Mwangi, M. M. A. \& Ngugi, K. (2014). Influence of entrepreneurial orientation on growth of micro and small enterprises in Kerugoya, Kenya. European Journal of Business Management, 1(11), 417-438.

Nahavandi, A. (2006). The art and science of leadership (4th Ed.). Upper Saddle River, NJ: Pearson Prentice Hall.

Oncer, A. Z. (2013). Investigation of the effects of transactional and transformational leadership on Entrepreneurial Orientation. International Journal of Business and Social Research, 3(4), 153-166.

Palalic, R. \& Busatlic, S. (2015). Exploratory research on relationship between entrepreneurial orientation dimensions and business performance and growth of fast and slow growing small and medium enterprises in Bosnia and Herzegovina. International Journal of Business and Management, 10(2), 1530.

Panagopoulos, N. G. \& Avlonitis, G. J. (2010). Performance implications of sales strategy: the moderating effects of leadership and environment. International Journal of Research in Marketing, 27(1), 46-57.

Shahraki, M. R. \& Bahraini, Z. (2013). An examination of the relationship between transformational leadership with entrepreneurial orientation in organization (Case Study: Mobin Petrochemical Company- South Pars). International Journal of Advanced Studies in Humanities and Social Science, 1(4), 274-289. 


\section{Journal of Economics and Behavioral Studies (ISSN: 2220-6140)}

Vol. 9, No. 2, pp. 104-113, April 2017

Soininen, J. (2013). Entrepreneurial Orientation in Small and Medium-Sized EnterprisesduringEconomicCrisis.Onlineatwww.doria.fi/bitstream/handle/10024/92169/isbn9789 522654472.pdf/Accessed on 6 October 2015.

Statistics South Africa. (2016). South Africa unemployment rate 2000-2016 Data Chart.Online at http://www.tradingeconomics.com/south-africa/unemployment-rate/Accessed on 04 April 2016.

Tarsik, N. F., Kassim, N. A. \& Nasharudin, N. (2014). Transformational, Transactional or Laissez-Faire: What Styles do University Librarians Practice? Journal of Organizational Management Studies, 2, 1-10.

Van der Merwe, S. P. \& de Swardt, G. (2008). Small business owner-managers' perceptions of entrepreneurship in the Emfuleni district. SAJEMS, 11(4), 449-464.

Van Geenhuizen, M., Middel, R. \& Lassen, A. H. (2008). Corporate entrepreneurship in SMEs during the search for discontinuous innovations. Online at http://vbn.aau.dk/files/ Accessed on 26 June 2015.

Wealthwise. (2014). More Women Entrepreneurs Puts Gender Parity Within Reach. Online at http://www.wealthwisemag.com/more-women-entrepreneurs-puts-gender-parity-withinreach/Accessed on 05 May 2016.

Yang, C. (2015). The relationships among leadership styles, entrepreneurial orientation, and business performance. Managing Global Transitions, 6(3), 257-275.

Yong, A. G. \& Pearce, S. (2013). A beginner's guide to factor analysis: Focusing on exploratory factor analysis. Tutorials in Quantitative Methods for Psychology, 9(2), 79-94.

Zulkifli, R. M. \& Rosli, M. M. (2013). Entrepreneurial orientation and business success of Malay entrepreneurs: religiosity as moderator. International Journal of Humanities and Social Science, 3(10), 264-275. 